\title{
KENYA'S PASTORAL NEEDS
}

\begin{abstract}
T 1929, an agricultural commission under Sir Daniel Hall reported on the grave condition to which certain native reserves in Kenya had been reduced as a consequenco of overgrazing and soil erosion, and recommended an immediato reduction in livestock and an increaso in agriculturo as means of countering $\Omega$ serious and growing menace to tho existence of the country. In 1931, Sir Frank Stock. dalo reported that an increaso in agriculture and consequent reduction of area available for grazing were accentuating the dangers of erosion. In 1933, the Kenya Land Commission recommended an extension of the cropped area, using dry-farming methods, in order to increase production in densely populated reserves. In 1936, Sir Alan Pim's report on Kenya directed attention to the danger of extending tho cultivated area without suitablo precautions being taken to maintain fertility, and to the absenco of any definito policy with regard to soil erosion. In 1937, both Sir Frank Stockdalo and the recently appointed soil conservation officer (Mr. C. Maher) expressed the viow that the overworked land needed a completo and prolonged rest without which much of it was irrotriovably doomed. They further recommended tho dovelopment and intensification of agriculture to compensate for loss of production from 'rested' land.
\end{abstract}

This summary of tho recommendations of some of the consulting 'physicians' who havo attended Kenya in the last ten years of its decline is given (in more dotail) in Dr. Polo-Evans's account of $n$ visit to tho Colony last year.* It will be noticed that all the other physicians recognized that the worst affected parts needed rest, but proposed to maintain productivo capacity by throwing an additional burden on to other parts, that is, by extending agriculture. That the productive capacity of the native reserves must bo maintained at $\mathrm{a}$ certain minimum in tho

- Report on a visit to Kenya. By Dr. I. B. l'ole-Evans. Pp. $36+18$ plates. (Nalrobl: Government Prititer, 1939.) 28. Cd. immediate interests of the inhabitants is the burden of theso physicians' argurnents. Dr. Polo-Evans is moro forthright in his recommendations. Ho is a South African ecologist who lacks the bedside manner of tho official reporter or commissioner. Ho considers that the situation is so grave that the complete rest which should hnvo beon given years ago is now imperative and must bo given regardless of economic and political obstacles, if a greater future disister is to bo avoided. 'The remedy he proposes is simplo on paper; it has been used timo and again in history to rest oxhausted land while keeping it under human control, and it has rarely. failed. It consists in restoring tho natural grass cover and utilizing animals in suitablo numbers to keep the grass in good condition. It means a goneral reversion to less productivo pastoral farming with greatly reduced stock in densely populated native reserves. Dr. Pole-Evans udmits tho valuo of supplementary ineasures of soil conservation-afforestation, terracing, strip-cropping, etc.-but they aro practically uscless unless the foundations of native society are grounded in pastures. Tho population can only support itsolf on a predominantly pastoral basis if administrative intelligence and action aro concentrated on the problom of growing luxuriant grass on exhausted land in a semi-arid climato. 'Tho solution of that problem will demand all the resources of scienco backed by wiso and far-sighted administration, and Dr. Pole.Evans's report is a plea that the necessary holp and encouragement of tho right kind be given before it is too lato.

The report is depressing in the oxtreme, but it carries deadly conviction. Ono wishes that it could be read and its implications understood by overy member of parliament. Wo might then get the beginnings of a Colonial policy which takes account of the harsh-the very harsh-realities of Nature that will dotermine policy in the end.

G. Y.J.

\section{THE ROYAL SOCIETY OF CANADA}

\section{Annual Meeting}

$\mathrm{T}$ HE annual meeting of the Royal Socioty of Canada was held at the University of Montreal in the now Botanical Building during May 22-24. A large attendance of fellows from all parts of Canada had an opportunity of soeing this splendid now dovelopment of a botanical garden in Montreal with its laboratories, greenhouses and largo park still in the progress of completion as a works project financed by civic and Government authorities and under the direction of Frère Marie-Victorin of the University of Montreal.

The presidential address was delivered by Dr. Victor IIorin, who spoke on "La Chanson Françaiso \& travers les siècles", with interpretations of songs by the "Quatuor des Alouettes" This address was preceded by the introduction of now fellows and by tho presentation of medals awarded by the Society.
The Flavello Medal was awarded posthumously to the late Prof. J. Mlayfair Mc.lurrich in recognition of his distinguished work in anatomy. Dr. Wilfred Hovey received the Lorne Pierce Medal, and the Tyrroll Medal was presonted to Dr. F. Z. Mussicutte. A unique social feature of the meoting was the Operotta-dinnor held in the ballroom of the Mount Royal Hotel, at which the fellows and their wives were the guests of tho City of Montreal. This fanciful dinner-play was written by tho president of the Society, Dr. Morin, as a reconstitution of the feasts given by the 'seigneurs' of olden times. Parodical rhymes on gastronomical subjects adapted to the music of well-known operas of the French repertory wero sung by artists in cook's and maid's cos. tumes, as the several dishes of the dinner were served. 
At the concluding general meeting, Dr. H. M. Tory was elected the new president of the Society.

Section III (Chemical, Mathematical and Physical Sciences) was held under the presidency of Prof. S. Beatty, who delivered the presidential address on "Generalisation as a Principle of Mathematics". Three new members were elected to this section, Prof. H. N. Brocklesby, Prof. II. F. Crawford and Prof. G. Herzberg. In all, 120 papers were presented and the section split into the three subdivisions to facilitate the giving of the papers during the time of the meeting.

Prof. E. F. Burton spoko on a number of papers contributed by his co-workers, among which special mention should be made of the recent results obtained by Johns, Wilhelm and Grayson Smith on the flow and viscosity of liquid helium, in which it was proved, by using glass capillaries ranging from $0.025 \mathrm{~cm}$. to $0.0036 \mathrm{~cm}$. in diameter and with lengths varying from $2 \mathrm{~cm}$. to $26 \mathrm{~cm}$., that normal laminar flow was obtained for $\mathrm{He}$ I with a viscosity of the order of $10^{-5}$ c.g.s. units, while for $\mathrm{He}$ II, the flow could bo expressed as tho sum of a laminar flow plus an additional pressure-independent flow. The laminar portion obeyed Poiseuille's law and gave a viscosity of the order of $10^{-5} \mathrm{c.g} . \mathrm{s}$. units. The new electron microscopo constructed by A. Prebus and J. Hillier and photographs obtained with it indicating high resolving power wero described by Dr. Burton. Among the papers presented by Prof. J. A. Gray, one in collaboration with J.S. Marshall and A. G. Wood contained results on the scattering of $\beta$-rays using metallic foils, which were in contradiction to those obtained by other observers using expansion chamber mothods. Dr. D. C. Roso described an electromagnetic pick-up device used with a cathode ray oscillograph for investigating vibrations in aeroplanes during flight. A now mothod of observing the Raman effect in small amounts of liquid with short exposure times was presented by Prof. M. F. Crawford and H. L. Walsh.

A description of tho methods now being used to determine the upper earth structure from data obtained by registering the seismic waves from rock bursts occurring in mines was given by Dr. E. A. Hodgson. Other papers on field results of geophysical investigations were given by $\mathrm{Dr}$. A. A. Brant, Prof. L. Gilchrist and Prof. D. A. Keys. The results of an analysis of meteorological data by $\mathrm{A}$. Thomson showed that the average winter temperature was $4^{\circ} \mathrm{F}$. warmer in Manitoba and Saskatchewan for the period 1919-1938 than for the period 1884-1903, which was explained by the increase in the temperature of the air-masses moving in from the Arctic circle.

Among the fifteen papers presented by Prof. $O$. Maass and his associates, particular interest was taken in those dealing with the measurements of viscosity, opalescence, specific heat, density and solubility relations of various liquids and vapours in the critical temperature region. The influence of intense mechanical stirring on the temperature at which the disappearanco of the meniscus takes place shows that a wide range of over-all density gives identical critical temperatures. Prof. E. W. Steacio presented eight papers dealing with various aspects of photosensitized decomposition. Prof. R. H. Clark and his collaborators contributed fourteen papers, among which special mention may be made of the results obtained on activators of zymase. The plant hormones activate live yeast but havo little accelerating effect on zymin. Another paper of interest was on the mechanism of the flotation of galena in the presence of xanthate which is applied in the mining industry in Canada. Prof. H. Hibbert spoke on the results obtained in his laboratory, carried out with various collaborators, on lignin and other wood products.

In the mathematical and astronomical section, M. S. McPhail and Prof. R. L. Jeffery spoke on Stieltjes integrals with applications to fractional integrals. The profiles of hydrogen lines in the spectrum of H.D. 190073 by C. S. Beals and an investigation into the hydrogen line contours in the spectra of solar stars by K. O. Wright were given by Dr. WV. E. Harper. Dr. A. V. Douglas, D. C. West and D. E. Guignard described an investigation on the profiles of hydrogen lines in two class $B$ stars.

Prof. J. A. Gray was elected president of the section and Prof. J. K. Robertson secretary.

In Section IV (Geological Sciences) the presidential address by Dr. MI. E. Wilson outlined the devolopment of ideas about the Canadian Precambrian and discussed certain Precambrian problems. Eighteen papers were presented. Two papers dealt with Sudbury, ono by Dr. H. C. Cooko, in which somo new ideas about the general geology of the district were given, and the other by Dr. A. B. Yates concerned with the oro deposition. Dr. H. C. Gunning and J. W. Ambrose outlined the results of fivo years detailed investigation of the so-called TimiskamingKeewatin contact in Rouyn-Harricanaw Area, Quebec. The whole succession of volcanic and sedimentary rocks is apparently conformable and the investigations show the need for complete revision of our conceptions of Archean stratiography and structure in this part of the Canadian shield.

The palæontological papers included descriptions of a Helderber fauna from the eastern townships of Quebec by D. T. H. Clark, and somo species of NeoTriassic ammonites by D. L. H. MeLearn. Dr. J. T. Wilson presented an interesting paper on the Eskers north-east of Great Slave Lake, N.W.T. The information was gained chiefly from the study of aerial photographs.

Dr. H. W. Fairbairn presented a paper on the fracture hypothesis of quartz orientation in tectonites. Dr. M. B. Baker discussed the floor of the Palæozoic rocks in Canada.

The presidential address of Section V (Biological Sciences) was delivered by Dr. J. M. Swaine of Ottawa on "Scientific Research as the Key to Progress in Agriculture".

The programme comprised seventy-two papers, of which nineteen came before the medical subsection, and twenty-nine were botanical.

Dr. N. H. Grace reported upon the relative physiological activity of the members of a series of naphthyl acids when applied to plant cuttings, showing that those with an even number of carbon atoms in the side chain are the more active. Drs. E. Gordon Young and R. Wr. Begg found certain small proportions of copper, calcium, magnesium, and iron to be required in bacterial culture media. Factors affecting stomatal movement in the dark were described by J. H. Whyte. That increased permeability of the host accompanies increased susceptibility to parasites and diseases in plants was shown by $F$. $S$. Thatcher. The-importance of boron for normal cell division, enlargement, and maturation in plants was 
ad by J. G. Coulson and R. O. Lachance, tudies related to hardiness of plants were d by Messrs. J. Levitt and D. Siminovitch. .homson discussed the structuro of the pollen Austrotaxus and its phylogenetic significance, $r$ it to be a highly specialized derivative of al conifer type, and $\mathrm{C}$. $\mathrm{N}$. Haldenby described ribution and origin of horizontal resin canals iferce. A series of papers by Frère Mario1 was devoted to various taxonomic and itional studies of the plants of Quebec and of interesting contributions to the problem of ras being made, particularly in papers by oussear and Gauthier.

he field of genetics, a definito relationship a sterility and chromosome segregation with sations was demonstrated in wheat crossed by Chompson, and the actual causes of failure of tting in certain intergeneric cereal crosses scribed in another paper by the same investiF. H. Peto gave an account of the production lo amphibolypoid plants from sterilo hybrids cum species, and A. Glaucum, by temperature chicine treatments, with cytological studies of icesses involved. Certain chromosome muta$x$ oats were shown by H. G. F. Sander to loss of all parts of one chromosome, and on the chromosomes of Trillium by G. B. and $H$. B. Nercombe gave data which cannot be fitted to any existing theory of crossing it suggest a new partial hypothesis.

ures of the morphology of the circulatory of Amia, particularly in relation to an airng mechanism, were described by $\mathrm{V}$. C. -Edwards, and the presence of a vessel of nature connecting the hypophysis and the almus in the frog was reported by $\mathrm{E}$. Horno - The latter also demonstrated wide and ant differences in the vascular richness of hypothalamic centres in the rat. Various studies on the white whale were reported by V. D. Vladykov, who also discussed sexual dimorphism in the speckled trout. F. E. J. Fry had a paper on density of lake trout populations. An account of differential growth rates and of regeneration in the hind limb of the frog was offered by A. Emerson Warren. A study of temperature relations of the numerous species of midges (Chironomidx) occurring in a lake was described by R. B. Miller.

B. P. Babkin and associates showed that ergosterol and parathyroid hormone effect gastric secretion in the dog chiefly by depressing its nervous phase. Early cessation of growth in rats on a rich fat diet was found by R. G. Sinclair and traced to the masking or suppression of synthesis of essential fatty acids. The effect of guaiacols on the respiratory passages was described by E. M. Boyd. Authentic noto. chordal tissue in a dermoid eyst of tho ovary was reported by J. L. Riopelle. The structure and development of certain renal tumours led P. Masson to believe that the metanephros is not mesodermal but is derived from tho neural crest; whilo his associate, P. Simard, found a constant nouroinsular complox in the mammalian apparatus. Drs. A. Scott and A. M. Fisher gave an account of the effects of certain chemicals in inactivating insulin and showed by moving picturo film that each insulin crystal has two parallel square surfaces relatively close together, connected by four oblique quadrilateral surfaces. James Craigio showed that the Guarnieri inclusion bodies are probably not the intracollular colonies of a virus. The chemotactic attraction of staphylococci for Ieucocytes from mouse spleen was found by J. W. Stevenson and G. I3. Reed to vary inversely with pathogenicity, while Alma Howard reported an inverso relationship botween chiasma frequency in chromosomes and susceptibility to mammary gland carcinoma in mice.

\section{THE AGRICULTURAL EDUCATION ASSOCIATION}

\section{Annual Conference at Belfast}

AT science can do much to help agriculture ras the theme of several speakers at the Annual ence of the Agricultural Education Association was recently held at Belfast. Both Lord von (Prime Minister) and Sir Basil Brooke ter of Agriculture) referred with pride to the ements of the Education and Research Divisions Northern Ireland Government at the official of welcome, and reiterated the opinion that ion, both general and technical, is a sound nent. The Association, which met under the tanship of Mr. W. B. Mercer, had a long prote of scientific papers, interspersed with visits , Agricultural Research Institute at Hills,h, with its experimental farm of 500 acres, ant Breeding Station and Veterinary Research itory at Stormont, and farms of the Irish Peat pment Company at Maghery.

H. H. Corner directed attention to recent work ne' disease in sheep, which he declared was ent in the highlands of Scotland, the border counties, parts of Wales and in Devonshire. 'Pine' is an anæmic wasting disease due to a condition in which the iron of the food cannot be utilized by tho blood : the presence of numerous parasitic intestinal worms is a secondary condition. Following the success of Underwood in Australia, who in 1934 shorred that cobalt was the potent element in the utilization of iron compounds in enzootic marasmus, cobalt was tried in the treatment of 'pine' in the Cheviot region with great success. One ounce of cobalt chloride sprayed into and well mixed with one hundredweight each of steamed bone. flour and common salt, provided an easy means of preventing the disease, for the mixture could be set out in boxes for the animals to eat whenever they felt inclined. The cost was twopence a sheep per year.

Mr. James Mackintosh, as the result of two years experimental work with large numbers of cows in the south of England, suggested that a 20 per cent reduction might safely bo made in the amount of protein now being fed to dairy cows. He suggested a 